sciendo THE RING 41 (2019) 10.1515/ring-2019-0004

\title{
ESTIMATION OF THE AUTUMN MIGRATION PATTERN OF PASSERINES WITHIN THE SE EUROPEAN FLYWAY BY ORIENTATION CAGE TESTS
}

\author{
Przemysław Busse
}

\begin{abstract}
Busse P. 2019. Estimation of the autumn migration pattern of passerines within the SE European flyway by orientation cage tests. Ring 41: 43-64.

The general migration pattern of passerines can be estimated using a variety of methods. A number of partial analyses based on ringing data, usually limited to a few species, have been published. A very few continent-scale presentations have been offered, as extremely long periods of ringing activity are necessary for passerines. This is especially true for areas where the recovery rate is very low, including vast areas of north-eastern and eastern Europe and the Middle East/Africa. Similarly, radar and moon-watching studies are of limited value for drawing migration patterns within wider areas. Radar studies require good coverage by the radar systems, while weather radar distribution density and the level of evaluation are very uneven. Modern logger and satellite tracking are more applicable to non-passerines, and as yet enable detailed study only of limited numbers of individuals, and not population studies. At the end of the 20th century, a very simple tool was introduced for field studies on the preferred headings of individual birds caught for ringing, i.e. the use of flat orientation cages. This method was introduced as a standard within the SEEN (SE European Bird Migration Network) in 1995. This study presents a preliminary large-scale evaluation of the data collected within this project. The database used contains more than 43,000 orientation tests performed at 45 ringing sites. The area covered stretches from the northern part of western Russia to southern Egypt and from Italy and Poland to Siberia and Armenia. Eight streams of migration are identified within this area, creating a fairly complicated pattern of avian movements.
\end{abstract}

P. Busse, Bird Migration Research Foundation, Przebendowo 3, 84-210 Choczewo, Poland; e-mail: busse@wbwp-fund.eu

Keywords: migration pattern, passerines, autumn, SE European flyway, orientation cage data, network 


\section{INTRODUCTION}

The general migration pattern of passerines could theoretically be estimated using a variety of methods. A number of partial analyses presenting ringing data, usually limited to a few species, have been published. Very few continent-scale analyses have been presented for passerine species (e.g. Ashmole 1962, Busse 1969), as extremely long periods of ringing activity are required for passerines. The first ringing atlases by Schüz and Weigold (1931) and Zink (1973-1985) presented practically only raw ringing recoveries, while contemporary national ringing atlases (e.g. Fransson and Pettersson 2001, Wernham et al. 2002, Cepak et al. 2008, Spina et al. 2008, Bairlein et al. 2014) provide more detailed recovery patterns, but limited to a few countries. These patterns have a common weakness resulting from the ringing method - strong distribution biases due to differences in ringing recovery rates in different areas. This is especially true for areas where the recovery rate is very low, including vast areas of north-eastern and eastern Europe and the Middle East/Africa. This problem has been mentioned for many years, and there have even been attempts to solve it by taking local recovery rates into account (Coulson 1966, Snow 1966, Mead 1974, Busse and Kania 1977, Korner-Nievergelt et al. 2010). Such calculations, however, are only possible when high recovery numbers are available for the species. Similarly, radar and moon-watching studies are of limited value for drawing migration patterns within wider areas. Radar studies require good coverage by the radar systems, while weather radar distribution density is very uneven, even within Europe, but especially in the Middle East and Africa. These two methods provide data of limited value for studies on passerines, as this group of small migrants cannot be identified to the species level. Modern logger and satellite tracking are more applicable to non-passerines, and as yet are helpful for detailed work only on limited numbers of individuals, and not for population studies. Orientation cages were introduced in the middle of the last century (Kramer 1949, Sauer 1957), mainly for studies on the navigation abilities of migrants, and due to their construction were not useful in field conditions. A simpler orientation cage that can be used in field conditions was introduced in the 1960s ('Emlen's funnel' by Emlen and Emlen 1966). However, the method was not popular among fieldworkers. At the end of the 20th century a very simple tool was constructed specially for field studies on the preferred headings of individual birds caught for ringing (Busse 1995). 'Busse's flat orientation cage' was introduced as a standard within SEEN (the SE European Bird Migration Network) in 1995. A number of papers based on local heading patterns have been published (Formella and Busse 2002, Ściborska and Busse 2004, Adamska and Filar 2005, Adamska and Rosińska 2006, Rosińska and Adamska 2007, Stępniewska et al. 2011). A few papers discuss the details of evaluation methods (Busse and Trocińska 1999, Ożarowska et al. 2013, Busse 2017, 2018). The database has grown enormously over the years (to about 50,000 records), and data have been collected from nearly fifty sites. The area covered stretches from the northern part of western Russia to southern Egypt and from France and Morocco to Siberia and Armenia.

The main goal of this paper is to provide a large-scale overview of data collected during autumn migration and to estimate to what extent the method can draw a general 
picture of passerine migration, especially within the SE European Flyway. The picture contains data on all species caught and ringed at various sites, so it could be compatible with weather radar data if they are used in similar analyses. However, the aim of this paper is not to describe any species-specific population pattern; such patterns must be evaluated separately.

\section{STUDY AREA AND MATERIAL}

The study area (Fig. 1) covers mainly the SE European Flyway, but also includes a few sites located on the Central European Flyway (Croatia, Italy), as well as a few sites situated on the Atlantic Flyway (France, Spain and Morocco) and a site in Omsk, which clearly belongs to the Indian Flyway.

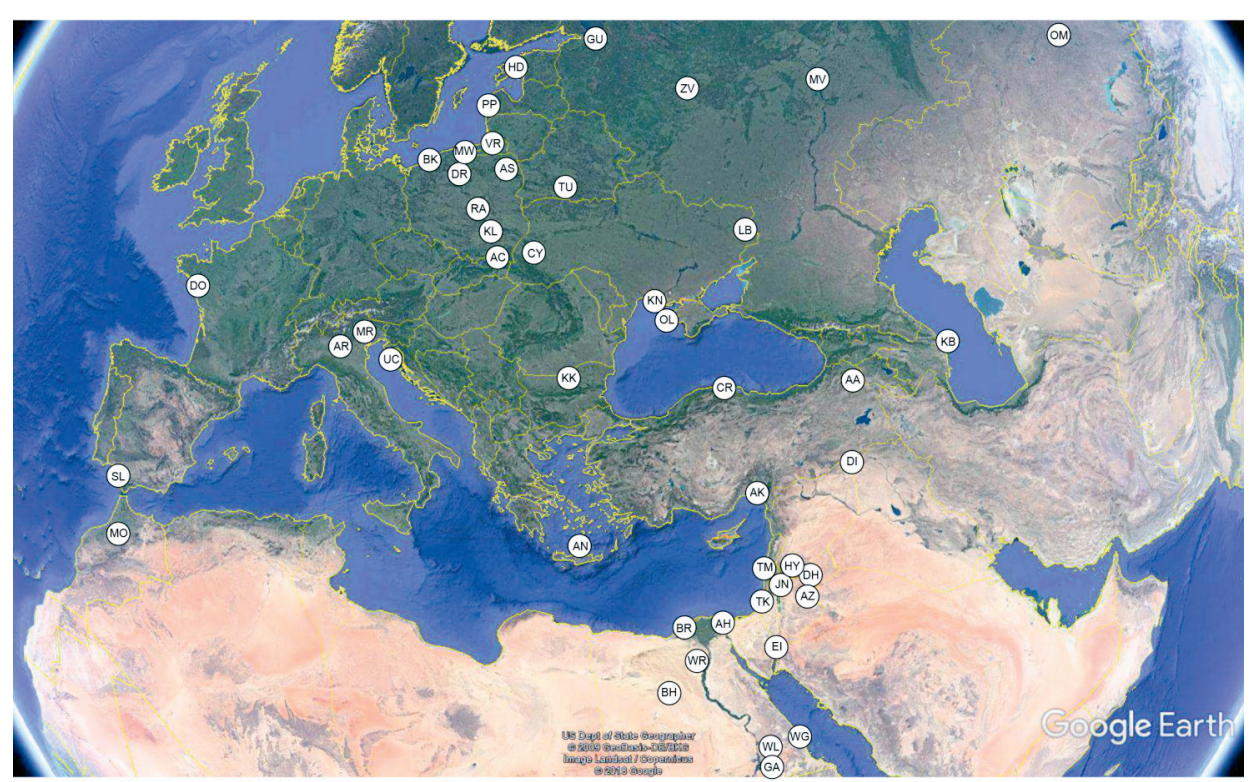

Fig. 1. Geographical distribution of the study sites. See Table 1 for list of letter codes

The list of sites, years, periods of work and numbers of individuals tested is given in Table 1. There are a few sites where data from several years and a vast number of birds were tested: the longest time spans are 14 years at Bukowo/Kopań (9439 birds tested) and 10 years at Mierzeja Wiślana (3048 individuals). At many sites, however, only a few autumn data are available (usually from one month). Even so, yearly samples at individual sites frequently numbered hundreds or even over a thousand tests. Therefore there is pronounced variation in the actual value of local directional patterns. Nevertheless, the sample sizes, in terms of number of sites (45) and number of tests performed $(43,546)$, are large enough to provide a general pattern of passerine movements on a wide geographic scale. 


\section{Table 1}

Data table of the material used. Geographical locations of the study sites can be found in Figure 1. The table shows the years and dates of the work, numbers of tested individuals, active ( $>40$ scratches) and non-active birds; percentage of non-active birds. *Birds in Morocco were tested partly using Emlen's funnel, and partly using Busse's cage; birds in Sanlucar were tested in Emlen's funnel.

\begin{tabular}{|c|c|c|c|c|c|c|c|c|}
\hline Code & Station/Country & Year & $\begin{array}{c}\text { Begin- } \\
\text { ning }\end{array}$ & End & Tested & Active & $\begin{array}{c}\text { Not } \\
\text { Active }\end{array}$ & $\%$ \\
\hline \multirow{2}{*}{$\mathrm{AA}$} & \multirow{2}{*}{ Aras, Turkey } & 2006 & 9 Sep. & 16 Nov. & 820 & 758 & 62 & 7.6 \\
\hline & & 2007 & 20 Aug. & 16 Oct. & 326 & 299 & 27 & 8.3 \\
\hline \multirow{5}{*}{$\mathrm{AC}$} & \multirow{5}{*}{ Carpatica, Poland } & 2000 & 11 Aug. & 21 Oct. & 412 & 384 & 28 & 6.8 \\
\hline & & 2001 & 6 Aug. & 9 Oct. & 149 & 143 & 6 & 4.0 \\
\hline & & 2002 & 6 Aug. & 8 Oct. & 182 & 172 & 10 & 5.5 \\
\hline & & 2004 & 7 Sep. & 28 Sep. & 175 & 158 & 17 & 9.7 \\
\hline & & 2005 & 3 Sep. & 31 Oct. & 252 & 244 & 8 & 3.2 \\
\hline \multirow{2}{*}{$\mathrm{AH}$} & \multirow{2}{*}{ Ashtoum, Egypt } & 2010 & 22 Sep. & 21 Oct. & 712 & 681 & 31 & 4.4 \\
\hline & & 2011 & 11 Oct. & 21 Oct. & 205 & 194 & 11 & 5.4 \\
\hline $\mathrm{AK}$ & Akyatan, Turkey & 2003 & 10 Sep. & 5 Oct. & 449 & 432 & 17 & 3.8 \\
\hline AN & Antikithira, Greece & 2009 & 17 Aug. & 21 Sep. & 235 & 225 & 10 & 4.3 \\
\hline \multirow{4}{*}{$\mathrm{AR}$} & \multirow{4}{*}{ Arosio, Italy } & 2005 & 28 Sep. & 28 Oct. & 323 & 308 & 15 & 4.6 \\
\hline & & 2007 & 22 Sep. & 28 Oct. & 370 & 347 & 23 & 6.2 \\
\hline & & 2008 & 20 Sep. & 29 Oct. & 390 & 363 & 27 & 6.9 \\
\hline & & 2009 & 22 Sep. & 29 Oct. & 214 & 204 & 10 & 4.7 \\
\hline \multirow{3}{*}{ AS } & \multirow{3}{*}{ Siemianówka, Poland } & 2002 & 4 Aug. & 11 Oct. & 459 & 408 & 51 & 11.1 \\
\hline & & 2003 & $11 \mathrm{Jul}$. & 1 Nov. & 867 & 696 & 171 & 19.7 \\
\hline & & 2004 & 5 Jul. & 2 Nov. & 955 & 760 & 195 & 20.4 \\
\hline \multirow{2}{*}{$\mathrm{AZ}$} & \multirow{2}{*}{ Azraq, Jordan } & 2002 & 28 Aug. & 12 Oct. & 197 & 176 & 21 & 10.7 \\
\hline & & 2003 & 12 Oct. & 21 Oct. & 38 & 36 & 2 & 5.3 \\
\hline $\mathrm{BH}$ & Bahariya, Egypt & 2010 & 28 Aug. & 15 Sep. & 63 & 63 & 0 & 0.0 \\
\hline \multirow{14}{*}{$\mathrm{BK}$} & \multirow{14}{*}{ Bukowo/Kopań, Poland } & 1995 & 2 Sep. & 28 Oct. & 322 & 237 & 85 & 26.4 \\
\hline & & 1996 & $1 \mathrm{Sep}$. & 17 Oct. & 739 & 625 & 114 & 15.4 \\
\hline & & 1997 & 15 Aug. & 6 Oct. & 744 & 674 & 70 & 9.4 \\
\hline & & 1998 & 19 Aug. & 24 Oct. & 528 & 496 & 32 & 6.1 \\
\hline & & 1999 & 23 Aug. & 5 Oct. & 511 & 495 & 16 & 3.1 \\
\hline & & 2000 & 15 Aug. & 13 Oct. & 299 & 282 & 17 & 5.7 \\
\hline & & 2001 & 16 Aug. & 19 Oct. & 883 & 810 & 73 & 8.3 \\
\hline & & 2002 & 18 Aug. & 28 Oct. & 1085 & 1008 & 77 & 7.1 \\
\hline & & 2004 & 18 Aug. & 27 Oct. & 585 & 550 & 35 & 6.0 \\
\hline & & 2005 & 13 Aug. & 15 Oct. & 1104 & 1051 & 53 & 4.8 \\
\hline & & 2006 & 15 Aug. & 27 Sep. & 719 & 693 & 26 & 3.6 \\
\hline & & 2007 & 12 Aug. & 2 Nov. & 748 & 693 & 55 & 7.4 \\
\hline & & 2008 & 14 Aug. & 13 Nov. & 574 & 527 & 47 & 8.2 \\
\hline & & 2010 & 20 Aug. & 25 Sep. & 598 & 571 & 27 & 4.5 \\
\hline \multirow{3}{*}{$\mathrm{BR}$} & \multirow{3}{*}{ Burullus, Egypt } & 2005 & $1 \mathrm{Sep}$. & 2 Nov. & 951 & 891 & 60 & 6.3 \\
\hline & & 2006 & 28 Aug. & 4 Nov. & 588 & 550 & 38 & 6.5 \\
\hline & & 2007 & 3 Sep. & 3 Nov. & 451 & 436 & 15 & 3.3 \\
\hline
\end{tabular}




\begin{tabular}{|c|c|c|c|c|c|c|c|c|}
\hline Code & Station/Country & Year & $\begin{array}{l}\text { Begin- } \\
\text { ning }\end{array}$ & End & Tested & Active & $\begin{array}{c}\text { Not } \\
\text { Active }\end{array}$ & $\%$ \\
\hline \multirow{4}{*}{$\mathrm{CR}$} & \multirow{4}{*}{ Cernek, Turkey } & 2002 & 18 Aug. & 28 Oct. & 1069 & 1004 & 65 & 6.1 \\
\hline & & 2003 & 16 Aug. & 24 Oct. & 994 & 889 & 105 & 10.6 \\
\hline & & 2004 & 16 Aug. & 25 Oct. & 1219 & 1131 & 88 & 7.2 \\
\hline & & 2009 & 12 Aug. & 13 Oct. & 544 & 490 & 54 & 9.9 \\
\hline \multirow{10}{*}{$\mathrm{CY}$} & \multirow{10}{*}{ Cholgyni, Ukraine } & 1996 & 19 Aug. & 5 Sep. & 56 & 48 & 8 & 14.3 \\
\hline & & 1997 & 3 Aug. & 28 Aug. & 45 & 30 & 15 & 33.3 \\
\hline & & 1998 & 4 Aug. & 26 Aug. & 17 & 15 & 2 & 11.8 \\
\hline & & 1999 & $21 \mathrm{Jul}$. & 29 Aug. & 63 & 49 & 14 & 22.2 \\
\hline & & 2000 & 16 Aug. & 16 Aug. & 8 & 8 & 0 & 0.0 \\
\hline & & 2001 & 8 Aug. & 27 Aug. & 67 & 47 & 20 & 29.9 \\
\hline & & 2002 & 4 Aug. & 2 Sep. & 95 & 63 & 32 & 33.7 \\
\hline & & 2003 & 6 Aug. & 28 Aug. & 117 & 94 & 23 & 19.7 \\
\hline & & 2004 & 4 Aug. & 24 Aug. & 111 & 78 & 33 & 29.7 \\
\hline & & 2005 & 3 Aug. & 26 Aug. & 614 & 494 & 120 & 19.5 \\
\hline $\mathrm{DH}$ & Dhleil, Jordan & 2002 & 26 Aug. & 4 Nov. & 1184 & 1120 & 64 & 5.4 \\
\hline \multirow{3}{*}{ DI } & \multirow{3}{*}{ Dicle, Turkey } & 2003 & 24 Sep. & 7 Oct. & 391 & 369 & 22 & 5.6 \\
\hline & & 2004 & 9 Sep. & 28 Oct. & 772 & 719 & 53 & 6.9 \\
\hline & & 2005 & 2 Sep. & 19 Oct. & 494 & 425 & 69 & 14.0 \\
\hline DO & Donges, France & 2011 & 6. Aug. & 24 Aug. & 414 & 381 & 33 & 8.0 \\
\hline \multirow{8}{*}{$\mathrm{DR}$} & \multirow{8}{*}{ Druzno, Poland } & 1996 & 7 Aug. & 30 Aug. & 100 & 78 & 22 & 22.0 \\
\hline & & 1999 & 3 Aug. & 9 Sep. & 84 & 79 & 5 & 6.0 \\
\hline & & 2000 & 1 Aug. & 13 Oct. & 456 & 393 & 63 & 13.8 \\
\hline & & 2002 & 5 Aug. & 2 Sep. & 487 & 465 & 22 & 4.5 \\
\hline & & 2004 & $28 \mathrm{Jul}$. & 4 Sep. & 512 & 469 & 43 & 8.4 \\
\hline & & 2005 & $31 \mathrm{Jul}$. & 2 Sep. & 444 & 424 & 20 & 4.5 \\
\hline & & 2006 & $30 \mathrm{Jul}$. & 2 Sep. & 305 & 286 & 19 & 6.2 \\
\hline & & 2007 & 27 Aug. & 3 Sep. & 72 & 67 & 5 & 6.9 \\
\hline \multirow{2}{*}{ EI } & \multirow{2}{*}{ Eilat, Israel } & 1999 & 24 Nov. & 9 Dec. & 87 & 69 & 18 & 20.7 \\
\hline & & 2002 & 12 Oct. & 5 Nov. & 212 & 128 & 84 & 39.6 \\
\hline \multirow{2}{*}{ GA } & \multirow{2}{*}{ Ghazala, Egypt } & 2003 & 31 Aug. & 27 Oct. & 366 & 352 & 14 & 3.8 \\
\hline & & 2004 & 17 Aug. & 14 Oct. & 335 & 331 & 4 & 1.2 \\
\hline \multirow{2}{*}{$\mathrm{GU}$} & \multirow{2}{*}{ Gumbaritsy, Russia } & 2000 & $26 \mathrm{Jul}$. & 29 Aug. & 305 & 281 & 24 & 7.9 \\
\hline & & 2001 & 10 Sep. & 30 Sep. & 519 & 396 & 123 & 23.7 \\
\hline \multirow{2}{*}{ HA } & \multirow{2}{*}{ Haademeeste, Estonia } & 1996 & $30 \mathrm{Jul}$. & 27 Aug. & 52 & 45 & 7 & 13.5 \\
\hline & & 2001 & 13 Sep. & 20 Sep. & 126 & 109 & 17 & 13.5 \\
\hline HY & Hashymiiya, Jordan & 2001 & $1 \mathrm{Sep}$. & 23 Sep. & 582 & 562 & 20 & 3.4 \\
\hline $\mathrm{JE}$ & Jenin, Palestine & 2016 & 9 Sep. & 3 Oct. & 37 & 35 & 2 & 5.4 \\
\hline $\mathrm{KB}$ & Karabogaz, Armenia & 2004 & 31 Aug. & 10 Sep. & 284 & 277 & 7 & 2.5 \\
\hline \multirow{4}{*}{$\mathrm{KL}$} & \multirow{4}{*}{ Kaliszany, Poland } & 2001 & 6 Aug. & 4 Oct. & 268 & 220 & 48 & 17.9 \\
\hline & & 2002 & 30 Aug. & 10 Sep. & 100 & 85 & 15 & 15.0 \\
\hline & & 2006 & 28 Aug. & 5 Oct. & 219 & 202 & 17 & 7.8 \\
\hline & & 2007 & 16 Aug. & 17 Oct. & 387 & 382 & 5 & 1.3 \\
\hline $\mathrm{KN}$ & Kinburn, Ukraine & 2001 & 13 Sep. & 17 Sep. & 126 & 109 & 17 & 13.5 \\
\hline LB & Lebedivka, Ukraine & 2001 & 29 Sep. & 28 Oct. & 64 & 61 & 3 & 4.7 \\
\hline
\end{tabular}




\begin{tabular}{|c|c|c|c|c|c|c|c|c|}
\hline Code & Station/Country & Year & $\begin{array}{c}\text { Begin- } \\
\text { ning }\end{array}$ & End & Tested & Active & $\begin{array}{c}\text { Not } \\
\text { Active }\end{array}$ & $\%$ \\
\hline MO & Morocco, Morocco* & 2002 & 31 Aug. & 6 Oct. & 105 & 84 & 21 & 20.0 \\
\hline MR & Malga Rosello, Italy & 2002 & 10 Sep. & 16 Oct. & 42 & 33 & 9 & 21.4 \\
\hline \multirow{3}{*}{ MV } & \multirow{3}{*}{ Makarovka, Russia } & 1998 & 24 Aug. & 2 Sep. & 82 & 52 & 30 & 36.6 \\
\hline & & 2000 & $29 \mathrm{Jul}$. & 24 Aug. & 365 & 322 & 43 & 11.8 \\
\hline & & 2001 & 14 Sep. & 20 Sep. & 20 & 20 & 0 & 0.0 \\
\hline \multirow{10}{*}{ MW } & \multirow{10}{*}{$\begin{array}{l}\text { Mierzeja Wiślana, } \\
\text { Poland }\end{array}$} & 1996 & 2 Aug. & 1 Nov. & 230 & 211 & 19 & 8.3 \\
\hline & & 1998 & 17 Aug. & 27 Oct. & 373 & 357 & 16 & 4.3 \\
\hline & & 2000 & 27 Aug. & 28 Oct. & 73 & 68 & 5 & 6.8 \\
\hline & & 2001 & 15 Aug. & 31 Oct. & 271 & 255 & 16 & 5.9 \\
\hline & & 2002 & 18 Aug. & 26 Oct. & 452 & 407 & 45 & 10.0 \\
\hline & & 2003 & 29 Aug. & 22 Oct. & 320 & 311 & 9 & 2.8 \\
\hline & & 2004 & 24 Aug. & 29 Oct. & 307 & 297 & 10 & 3.3 \\
\hline & & 2005 & 18 Aug. & 14 Oct. & 462 & 446 & 16 & 3.5 \\
\hline & & 2007 & 15 Aug. & 11 Oct. & 228 & 218 & 10 & 4.4 \\
\hline & & 2008 & 19 Aug. & 13 Oct. & 332 & 318 & 14 & 4.2 \\
\hline $\mathrm{OL}$ & Olenevka, Ukraine & 2006 & 17 Aug. & 21 Sep. & 1275 & 1073 & 202 & 15.8 \\
\hline $\mathrm{OM}$ & Omsk, Russia & 2001 & 2 Aug. & 5 Oct. & 789 & 701 & 88 & 11.2 \\
\hline \multirow{3}{*}{ PP } & \multirow{3}{*}{ Pape, Latvia } & 2000 & 5 Sep. & 24 Oct. & 51 & 48 & 3 & 5.9 \\
\hline & & 2001 & 11 Sep. & 29 Sep. & 429 & 354 & 75 & 17.5 \\
\hline & & 2003 & 19 Sep. & 13 Oct. & 487 & 426 & 61 & 12.5 \\
\hline RA & Rakutowskie, Poland & 2010 & 21 Aug. & 2 Oct. & 309 & 265 & 44 & 14.2 \\
\hline SL & Sanlucar, Spain* & $\begin{array}{l}1985 \\
1987\end{array}$ & - & - & 250 & 250 & - & - \\
\hline TK & Talitha Kumi, Palestine & 2000 & 30 Aug. & 5 Oct. & 328 & 303 & 25 & 7.6 \\
\hline $\mathrm{TM}$ & Tulkarem, Palestine & 2015 & 12 sep. & 10 Oct. & 136 & 109 & 27 & 19.9 \\
\hline $\mathrm{TU}$ & Turov, Belarus & 2000 & 3 Sep. & 17 Sep. & 143 & 133 & 10 & 7.0 \\
\hline \multirow{2}{*}{$\mathrm{UC}$} & \multirow{2}{*}{ Ucka, Croatia } & 2007 & 13 Sep. & 15 Sep. & 49 & 46 & 3 & 6.1 \\
\hline & & 2014 & 7 Sep. & 8 Oct. & 626 & 580 & 46 & 7.3 \\
\hline VR & Ventes Ragas, Lithuania & 2004 & 19 Sep. & 1 Oct. & 324 & 225 & 99 & 30.6 \\
\hline WG & Wadi Gemal, Egypt & 2005 & 1 Sep. & 23 Oct. & 119 & 104 & 15 & 12.6 \\
\hline WL & Wadi Allaqi, Egypt & 2012 & 13 Sep. & 7 Oct. & 217 & 202 & 15 & 6.9 \\
\hline \multirow{2}{*}{ WR } & \multirow{2}{*}{ Wadi el Rayan, Egypt } & 2002 & 5 Sep. & 19 Oct. & 190 & 177 & 13 & 6.8 \\
\hline & & 2003 & 7 Oct. & 27 Oct. & 25 & 23 & 2 & 8.0 \\
\hline $\mathrm{ZV}$ & Zvenigorod, Russia & 1998 & 9 Sep. & 12 Sep. & 112 & 100 & 12 & 10.7 \\
\hline & TOTAL & & & & 43,546 & 39,517 & 4029 & 9.3 \\
\hline
\end{tabular}

\section{METHODS}

\section{General methods}

The field method used to collect data was primarily the Busse's orientation cage test procedure introduced in 1995 (Busse 1995) in the Operation Baltic/SEEN networks (only a very few data were collected using Emlen's funnel cage - Table 1). Tech- 
nical details of the Busse's cage procedure are described in field manuals by Busse (2000) and Busse and Meissner (2015). The field test output for a tested individual is 8 number values, representing headings of the bird in the 8-sector circular cage (Fig. 2).
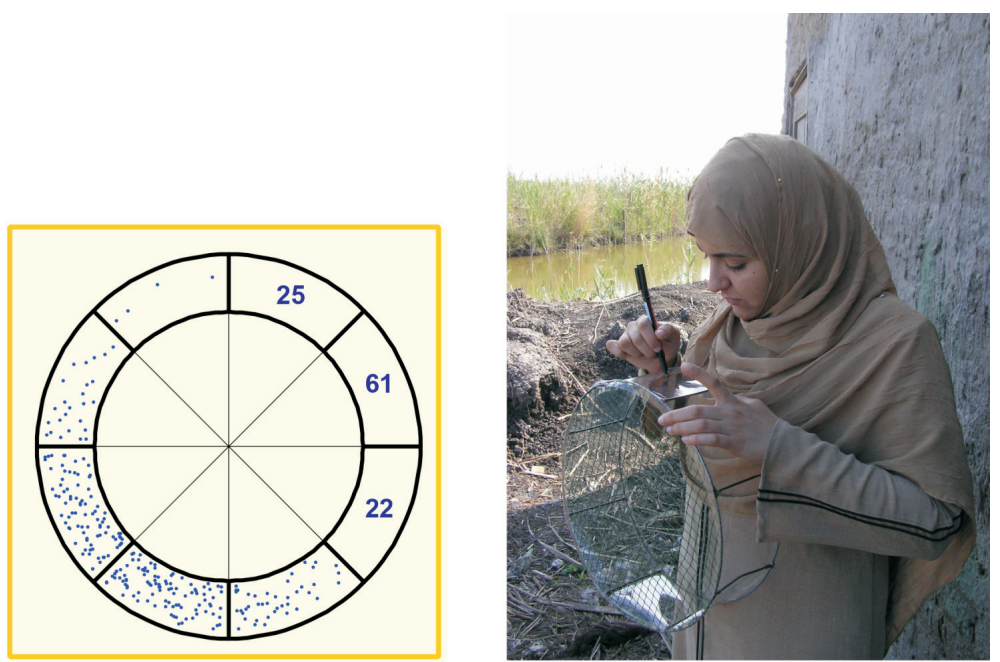

Fig. 2. Collecting raw orientation data

This individual test result was evaluated using Orient 4.6 software based on the fact that the data distribution may be multimodal (in contrast to the traditional Batschelet (1982) procedure, which requires that the distribution be unimodal). The problems with evaluations based on these procedures have been discussed in detail by Busse (2017). The group heading patterns (as in the example shown in Fig. 3) result from summing up the individual vectors obtained by evaluating the headings of individual birds. In this figure, the dots indicate estimated dominant directions: depending on

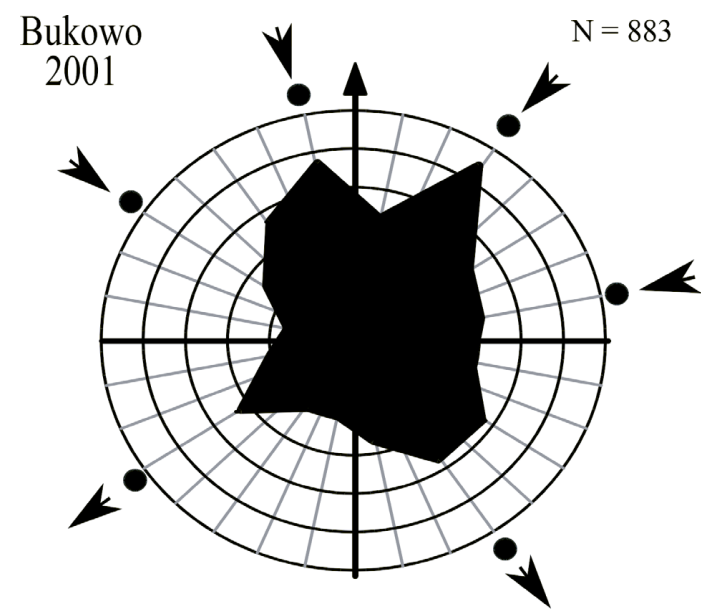

Fig. 3. Estimation of main headings from the distribution of individual headings of birds. Dots estimated main headings, arrows - assumed arrival and departure headings 
the season (only data from autumn are used here - see Table 1), the directions are interpreted as 'incoming' and 'outgoing' headings of the group. These interpretations are discussed in detail by Busse (2018).

As mentioned earlier, the number of seasons used in this work for 'site pattern' estimation was highly varied, so it was reasonable to check whether the results from a single season fit the pattern estimated for the site heading average based on multiyear data. As an example, the data from the longest time series of tests performed at Bukowo/Kopań were used for a methodological discussion.

\section{Methodological discussion}

Orientation tests were performed at the Bukowo/Kopań site during 14 seasons (1995-2010, except 2009). The number of tested birds per season varied, but the periods of work were nearly identical (Table 1), so the possibility of a time bias was limited. An example of the yearly result patterns is presented in Figure 4. The summary headings were varied, but at least some of them seem to be close to one another. In the past, data from seven seasons (2000-2006) were compared as to distribution of headings, and now other seasons (1995-1999, 2007-2010) were analysed in the same way, so we have two independent samples of seasons (Fig. 5) that may be compared. First, distributions of estimated yearly headings were checked using the chi-square test for uniformity of the locations of the headings within the wind-rose. In both samples, distributions were significantly not uniform (at the level of 0.001 and 0.01 ), but they were similar to each other $(p<0.05)$ and thus may be combined. Combined distributions of yearly headings (Fig. 6A) were significantly different from the uniform distribution $(p<0.001)$. Total headings as estimated directly from all individual birds
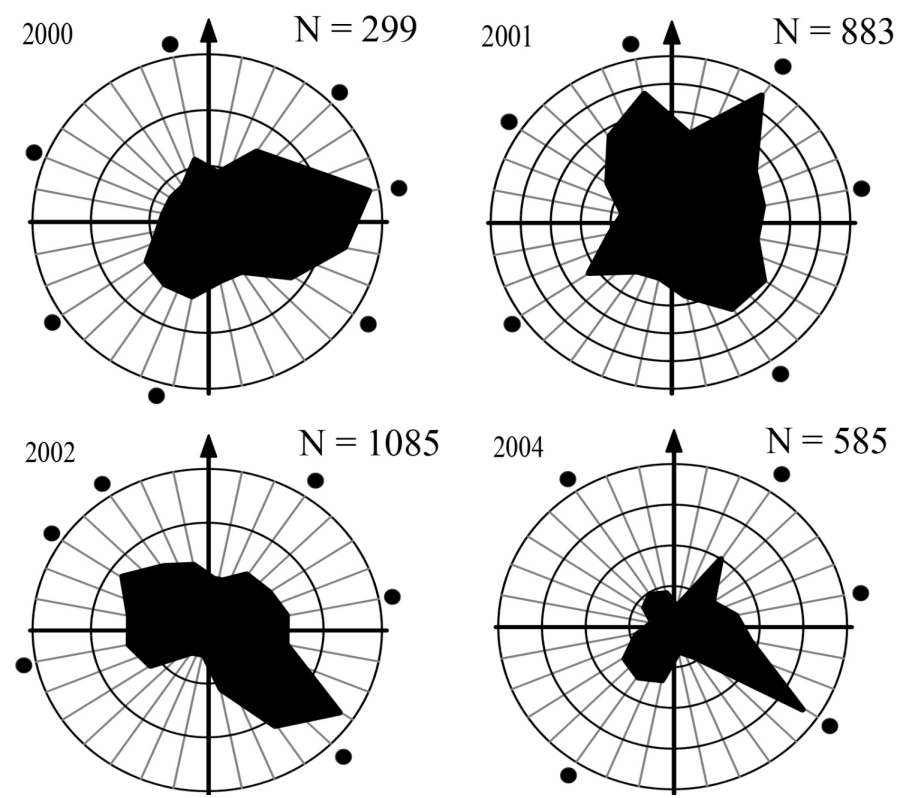

Fig. 4. Example of yearly distributions of headings at the Bukowo/Kopań site 
belonging to the compared groups were identical in four of five cases (Fig. 6B), while only NW incoming directions differed by about $20^{\circ}$.
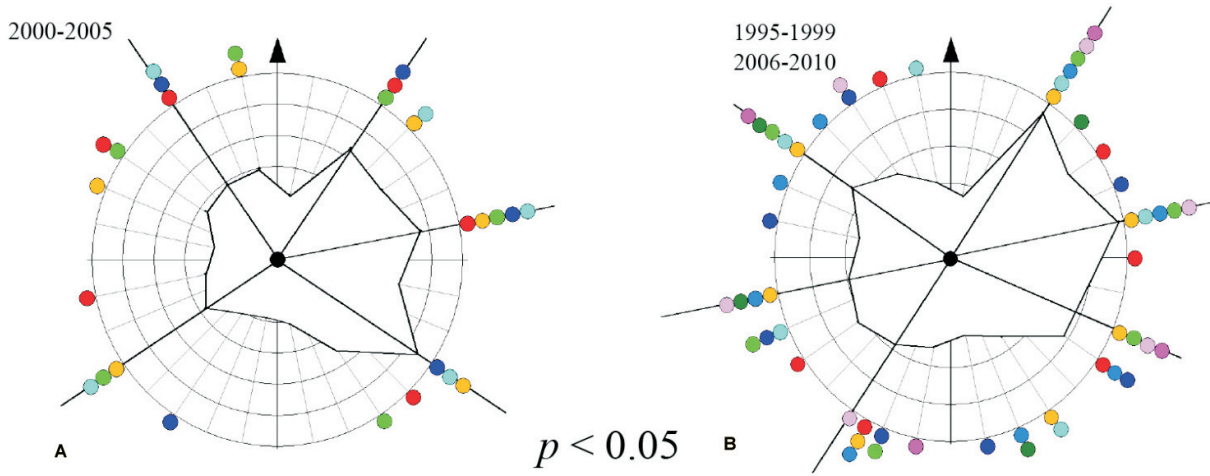

Fig. 5. Collected estimated yearly headings at Bukowo/Kopań. A. Sample for 2000-2006, B. Sample for 1995-1999 and 2007-2010. Distributions are similar at $p<0.05$.
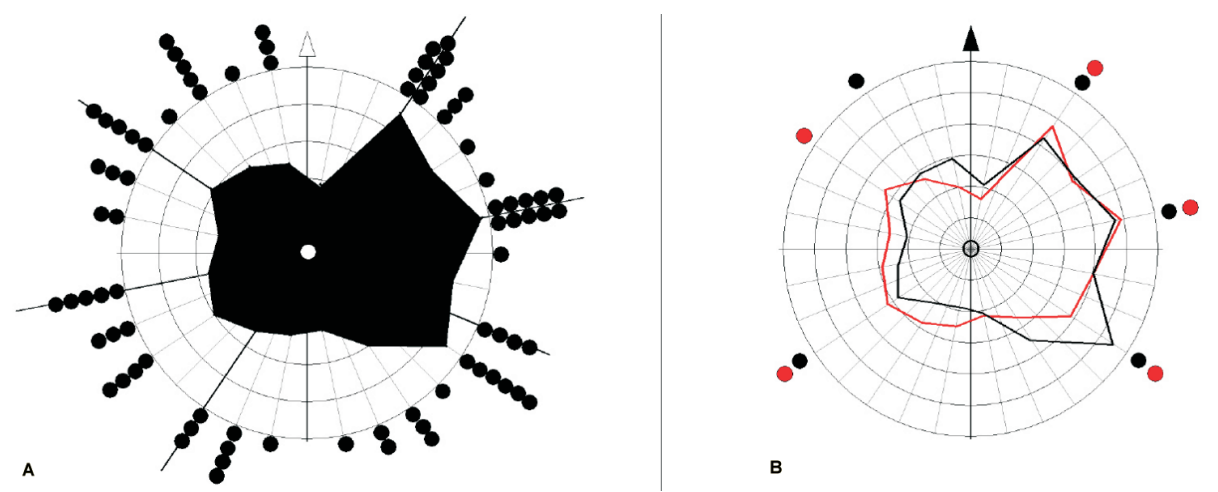

Fig. 6. A. Distributions of yearly headings at Bukowo/Kopań (1995-2010); B. Comparison of total samples: 2000-2006 - black lines and dots as in Fig. 5A; 1995-1999, 2007-2010 - red lines and dots as in Fig. 5B. Distributions are similar at $\mathrm{p}<0.05$.

In the case of the data from Bukowo/Kopan discussed here, we can estimate headings more precisely than from less numerous samples. This may be demonstrated using the aforementioned example by showing a 'flattened' form of the circular distribution from Figure 6A in Figure 7: (A) a smoothed distribution of estimated yearly headings suggests more real total headings demonstrated by the sample, (B) a return to the circular form of presentation shows one more interesting property of the headings: they are linear (NE-SW and ENE-WSW) or very close to linear (NW-SE - differing by only about $10^{\circ}$ ). This is a very common property in local distributions that will be discussed later and should be taken under consideration in estimations of the general pattern that is the result of this paper. 

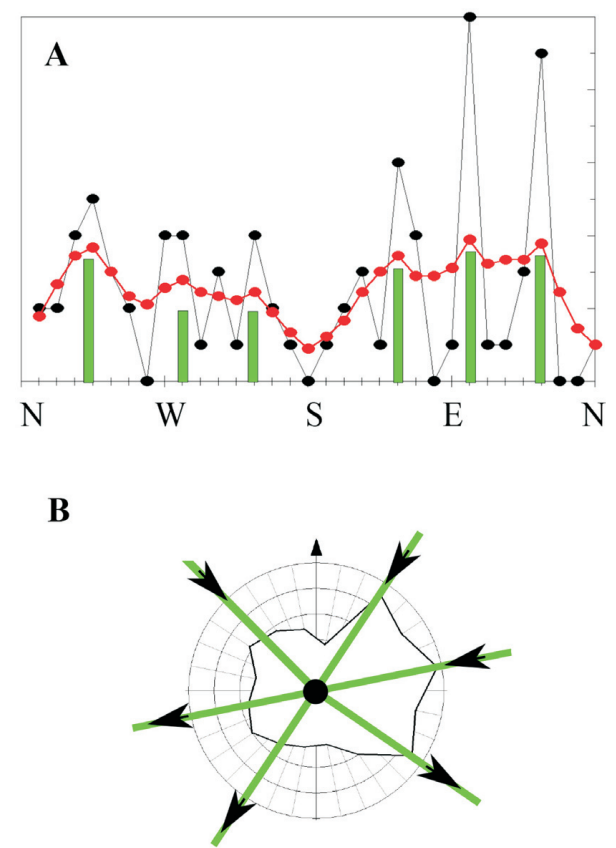

Fig. 7. A. Distribution of yearly headings at Bukowo/Kopań presented in linear form: black dots/line - number of yearly headings in 32 sectors (as for Fig. 6A), red dots/line smoothed by moving average, green - local maxima of the smoothed line; B. Circular total distribution of all individual headings (from 1995-2010) with headings as green bars in panel A and arrows showing arrival and departure directions. This presentation style is used in subsequent maps (Fig. 8-13).

\section{Geographical space estimation procedures}

All available data for every site (data from all years combined - Table 1) were used to prepare the local estimated heading pattern for a given site, as shown in Figure 7B total distribution as the background, with estimated main site headings. The local estimation patterns were then located in the appropriate location on the map as in Figure 8, which presents the local site patterns for Bukowo/Kopań and Mierzeja Wiślana. In the main step of the general estimation procedure the heading lines were uniformly coloured. After neighbouring sites were located, directional lines that were more or less similarly oriented were shown in the same colour. Then the arrival and apparently corresponding departure directions at the site are shown using the same colour. It should be mentioned that the lengths of the directional lines do not represent number relations between cohorts following these directions, but represent only directions from the site. Thus a long line does not mean that more birds migrate in this direction than in the direction represented by a short line. Taking under consideration the number of directional patterns at sites along the migration route, all local headings were classified as belonging to one of the migration streams passing the area under analysis. 


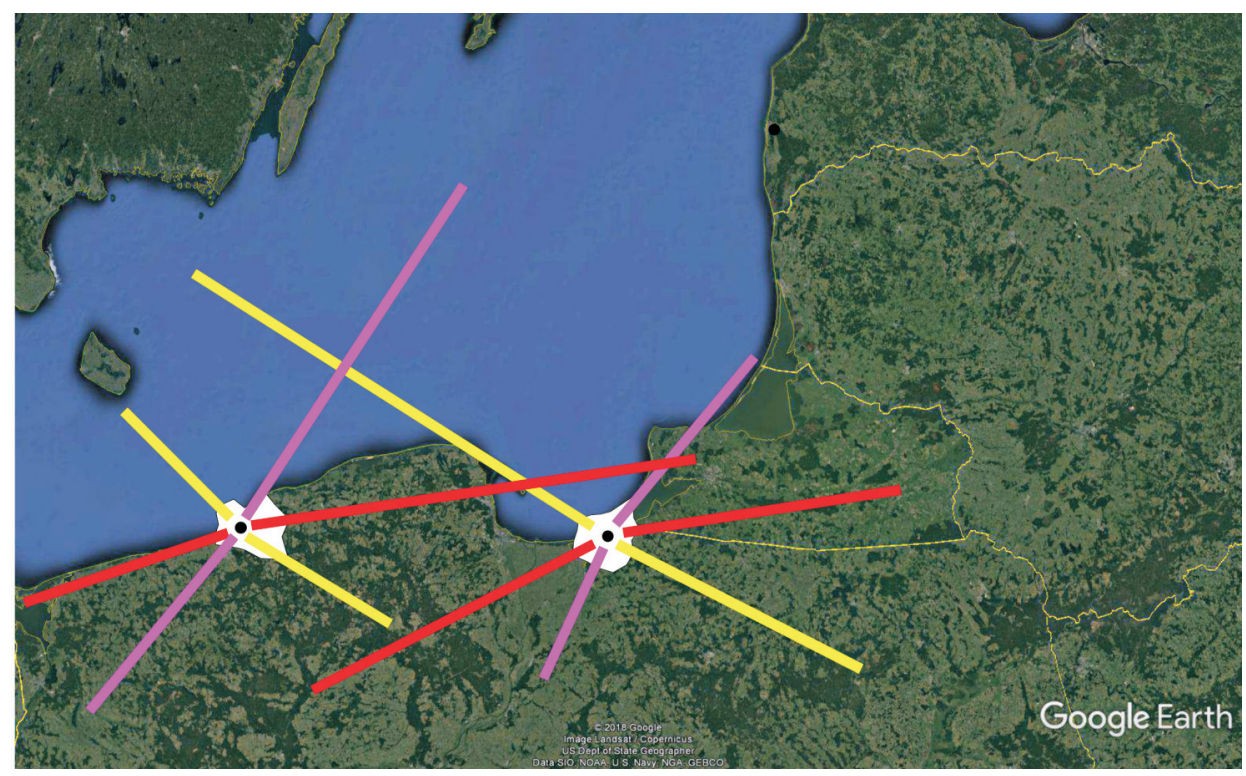

Fig. 8. Heading patterns on a map: Bukowo/Kopań (left) and Mierzeja Wiślana (right). White polygons - total individual heading distributions for the site; lines - main heading directions.

Taking under consideration which directional groups of birds are represented at each site, the general directions of migratory groups (represented by colours on the maps) were estimated (compare figures 11-13). The migration pattern in the entire area is definitely not 'stream-like' (see Fig. 14), but has a more 'carpet-like' structure. This can be presented as the polygon that shows area where defined headings are represented by migrants (compare Fig. 15, "Red" one polygon). That "carpet" of migrants moves to its own destination area symbolized by a red oval in Western Africa. At the similar way of maping of other group area shows that the carpets of migrants heading in different directions can overlap (see Figure 16). Identified groups can be individualy maped (see Figure 17).

The general pattern is finally presented as a combination of spaces where different migratory groups were observed. Because at every site birds belonging to several migratory groups are represented, the group areas overlap on the map (see Fig. 18).

Some important properties of the presented synthesis should be stressed.

(1) The term 'migratory group' here means 'the passerines migrating from the breeding area in a similar direction to different winter-quarters'. The breeding grounds could be within or outside the polygons defined by colours, as the polygons contain only study site distribution areas. Winter-quarters are situated somewhere outside or inside the study area and may be not common to different species. Only the direction of migration within the study area is common.

(2) The group pattern does not define the pattern of any specified species - the real species population structure may coincide with other species structures (they may be identical, similar or totally different), but they developed due to dispersion 
following the Ice Age, when the ice cap melted (commonly accepted since Busse 1969, Moreau 1972). This is in contrast with older research, whose authors believed that the migration system in Europe depended on contemporary mountain barriers (e.g., Rudebeck 1956, Dorst 1962). However, as the data include species identification of the birds tested, in the case of some more common species it is possible to analyse the heading patterns of individual species. This is a task for further studies.

\section{RESULTS AND DISCUSSION}

\section{Estimated headings at the study sites}

There are two areas where ringing/study sites were more concentrated than in other parts of the study area: Southern Baltic/Northern Poland (group of 7 sites - Fig. 9) and Middle East/Northern Egypt (10 sites - Fig. 10).

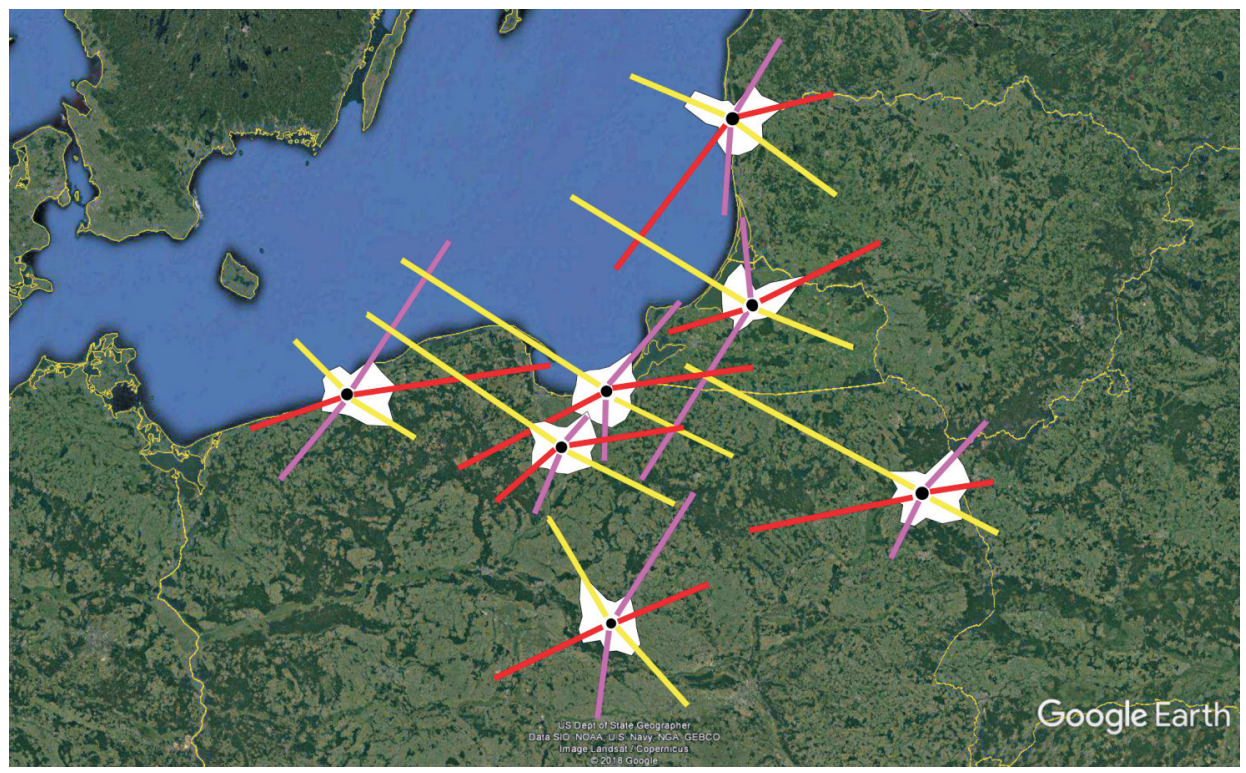

Fig. 9. South Baltic and northern Poland sites. Legend as for Fig. 8.

Within the former group, three headings may be suggested: two of them were more or less defined by the local guiding lines created by the Baltic sea, i.e. the eastern and southern sea coast - one directed more W-WSW (in red in Fig. 9), directed towards the Atlantic Flyway, and the other more SW-SSW (in violet in Figure 9), while a third heading crossed the southern coast line at about a $90^{\circ}$ angle, directed $\mathrm{SE}$, along the SE European Flyway. These patterns were common to both coastal and inland study sites.

The second area where studies were concentrated was the south-eastern Mediterranean Sea. There are three dominant headings: (1) very clear and concentrated ESE 
heading dominating in the northern part of this study area (north Israel/Palestine and Jordan); the flow of birds comes from the direction of Cyprus and is directed, surprisingly, towards the Arabian Desert (Fig. 10, yellow lines); (2) more SSE, coming from north-western Turkey/Crete and directed towards the east and west coasts of the Red Sea (orange lines); and (3) from the Caucasus/Caspian Sea areas, WSW-SW towards the heart of the Sahara Desert (blue lines), nearly perpendicular to the first two headings. The ESE headings are clear both near the Mediterranean coast (Tulkarem and Jenin; for site locations see Fig. 1/Table 1) and at the inland Jordanian sites (even Azraq, which is a desert oasis). The same applies to other study sites where coastal and inland sites show coherent directionality. Additionally, it must be stressed that at the northern sites (Tulkarem, Jenin and Jordan) incoming headings along the eastern Mediterranean are practically non-existent, despite the fact that this coastal guiding line is known as the main corridor for diurnal migration over Israel. It seems that the migration pattern of passerines is substantially different in this region from that of storks, pelicans and raptors. In this area passerines arrive from the sea and from inland far to the East, but not from the North.

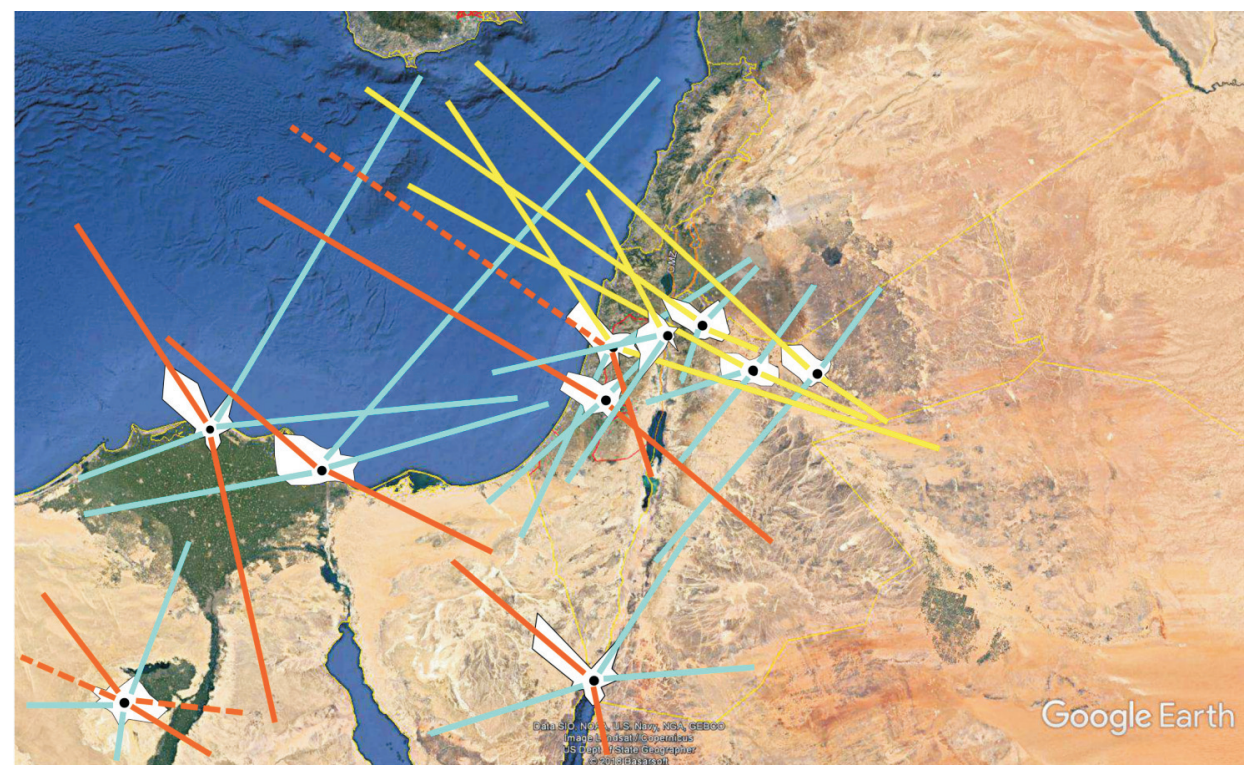

Fig. 10. Near East and northern Egypt sites. Legend as for Fig. 8.

Apart from the two concentrations of study sites described above, the data were evaluated for a number of sites dispersed over a vast territory, mainly covered by the known SE European Flyway (Balkans - Black Sea - the Caucasus - the Middle East Egypt), but in the west up to the northern Adriatic area (Central, Apennine Flyway) as well as to the Ural Mountains in the northeast (Fig. 11-12). On the Western Atlantic Flyway, there were only a few sites, located in France, Spain and Morocco (Fig. 13). The SE (Yellow) stream, so distinct in the Baltic area, continues over Eastern Europe 


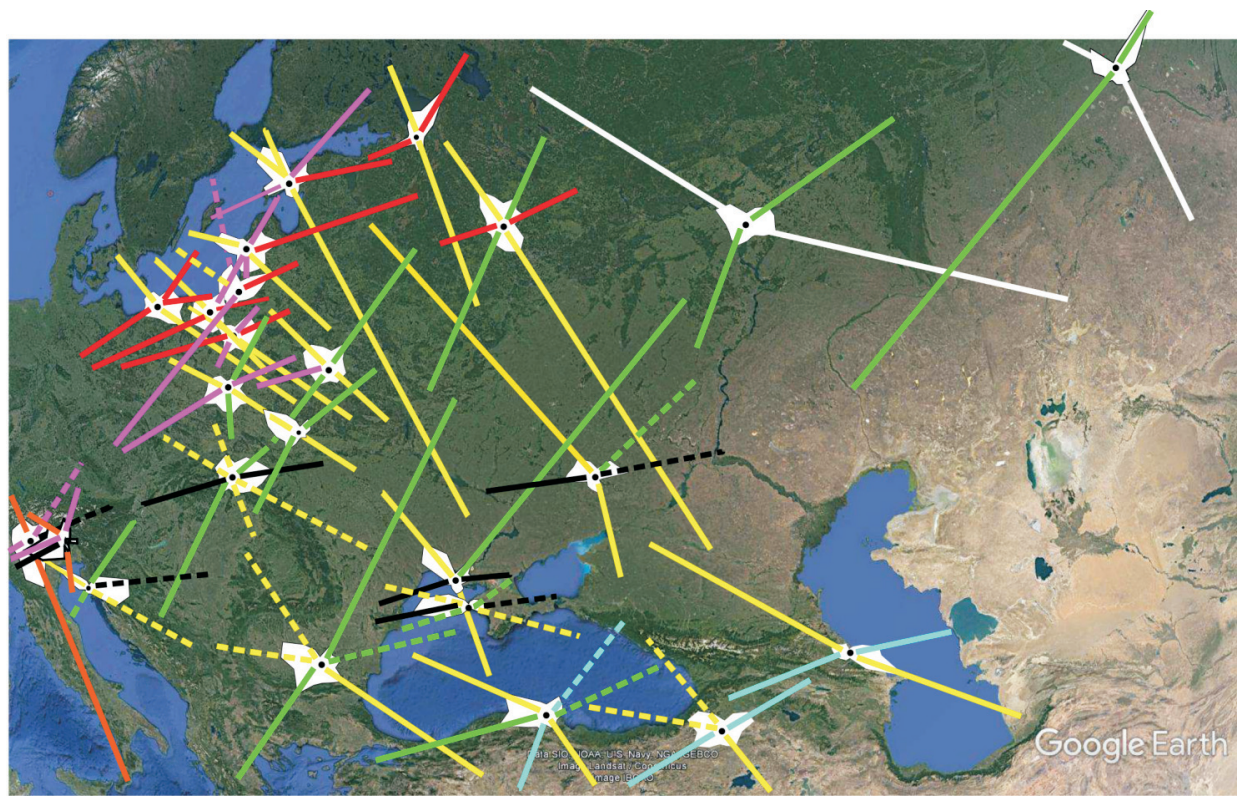

Fig. 11. Central and Eastern European sites. Legend as for Fig. 8.

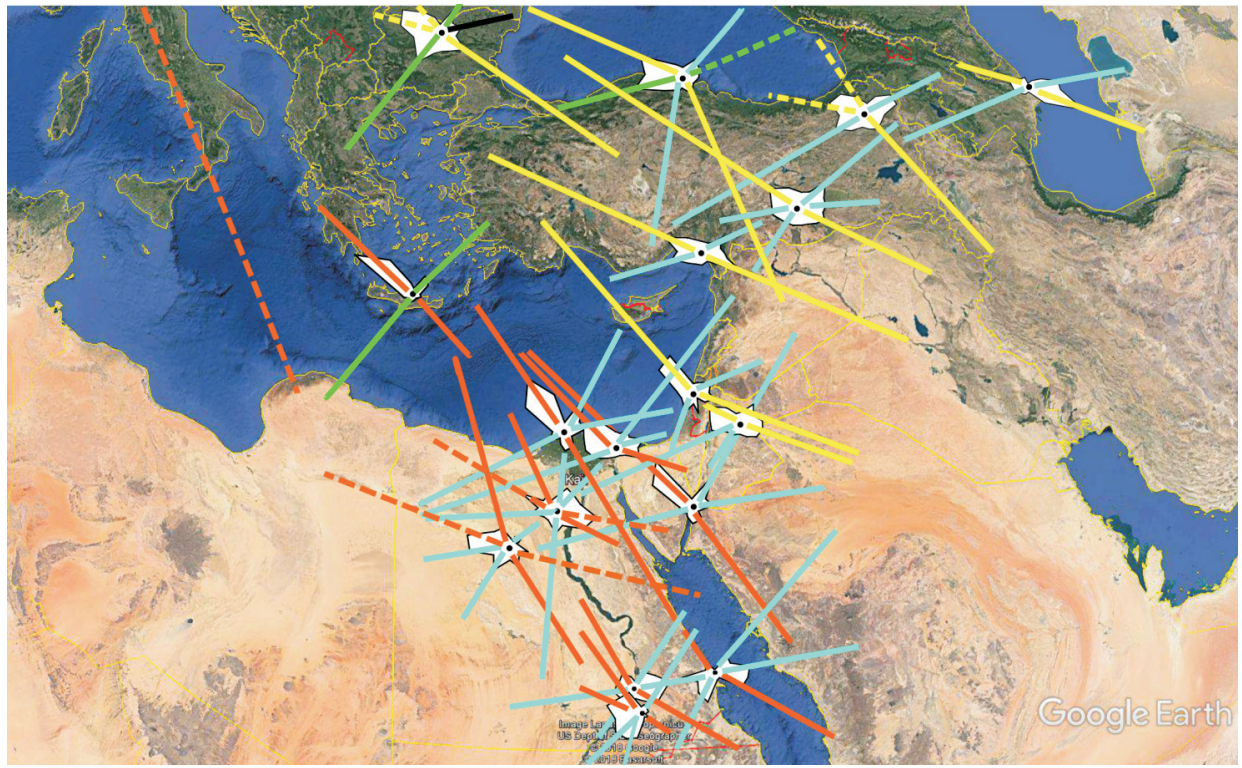

Fig. 12. Middle East and Egyptian sites. Legend as for Fig. 8.

and clearly follows the same coloured stream at the northern Middle East sites. Since two Baltic area streams (red and violet on the maps) follow the W/SW heading of the Atlantic Flyway, at a number of sites (from inland Polish sites even to the Ural area green on the maps) the SW stream is shifted to the east. It forms part of the Central Flyway crossing central and southern Italy as well as the Balkans. The easternmost 
followers of this stream could be found in western Turkey and Crete. The Green Stream crosses the Yellow Stream at nearly a $90^{\circ}$ angle. The source area of these populations is a vast inland territory of Belarus, Ukraine and western Russia. The next (Blue) migration stream can be defined by a line connecting central Turkey and the northern Caspian Sea area eastwards. This is clearly visible at the Caucasian/ Turkish sites (Karabogaz, Aras, Cernek, Dicle and Akyatan). Further on, this stream is strongly pronounced at the Middle East and Egyptian sites. The direction defined by the Eilat (Israel) and Egyptian headings is another surprise, as these birds seem to cross the Sahara by an extremely long flight in the direction of Chad. In southern Israel (Eilat) and eastern Egypt, besides the Blue Stream there is an SSE Orange Stream along the Red Sea, which up to now has been defined as the SE European Flyway leading to the East African winter-quarters. In fact, the Orange Stream is a continuation of the flyway originating somewhere in south-central Europe, and then heading through Italy, being a branch of the Central European Flyway (Fig. 13). Indian Flyway headings could be noted in the easternmost part of the study area (Makarovka, Omsk). Another, north-western stream from Scandinavia/Great Britain, belonging to the Atlantic Flyway, was seen in France (Donges) and probably in Spain (Sanlucar) and Morocco. These areas are, however, not covered by enough study sites. Completely hidden under these streams there is a Black Stream heading nearly longitudinally from the area of the Lower Volga/northern Caspian Sea to northern Italy (and probably further). This could be a branch of the Violet Stream heading commonly to the western Mediterranean islands and eastern Spain. The problem cannot be solved at this time due to insufficient data from Romania, Hungary and Austria. The most painful gap in the study data is the total lack of research sites on the Arabian Peninsula; beyond the Yellow Stream in the north, we do not yet know the movements of the passerine populations.

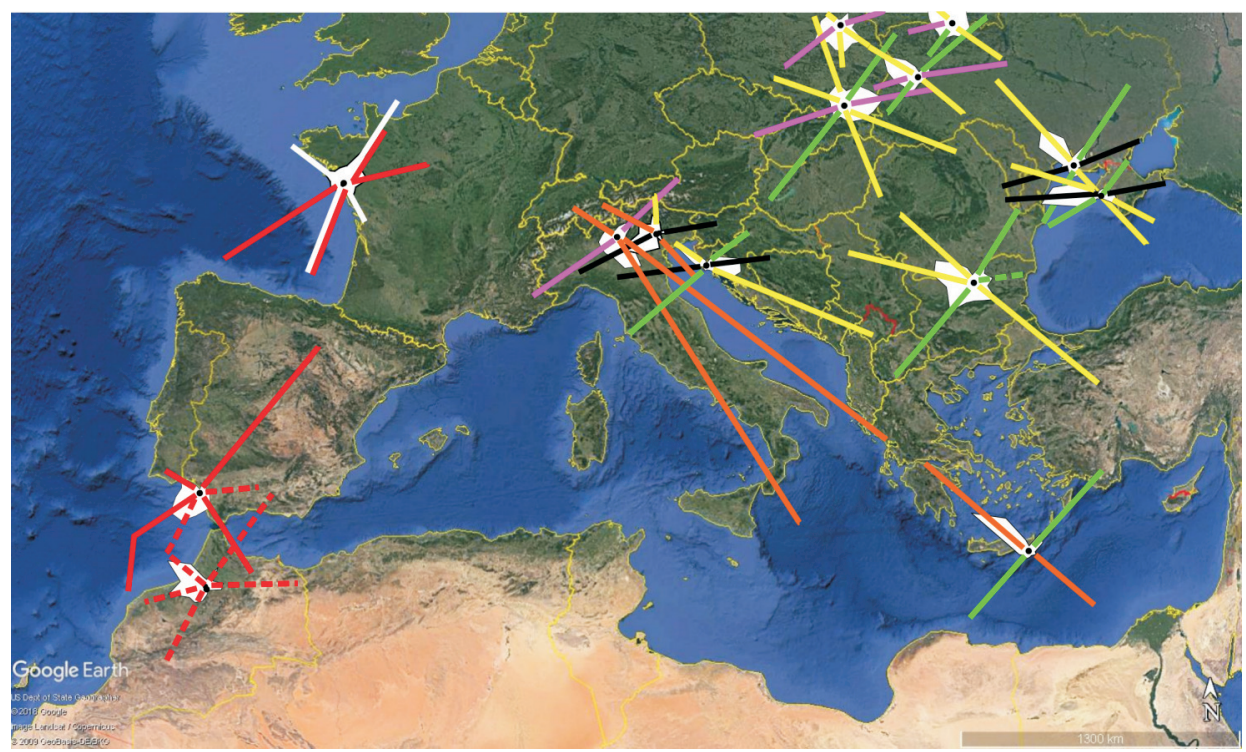

Fig. 13. Southern and Western European sites. Legend as for Fig. 8. 
The partial pictures (Fig. 11-13) can be combined into the more general pattern shown in Figure 14. Taking under consideration the local heading composition, the main heading pattern over the study area could be estimated. The figure shows two versions of the stream pattern discussed above, taking into account the problems of the Green and Violet/Black Streams. Adding more study sites in the areas under discussion, i.e. the northern Balkans, Ukraine and Russia, could clarify the structure of the streams. Passerine migration over the area from the Persian Gulf - southern Red Sea - Horn of Africa remains entirely beyond the scope of estimation.
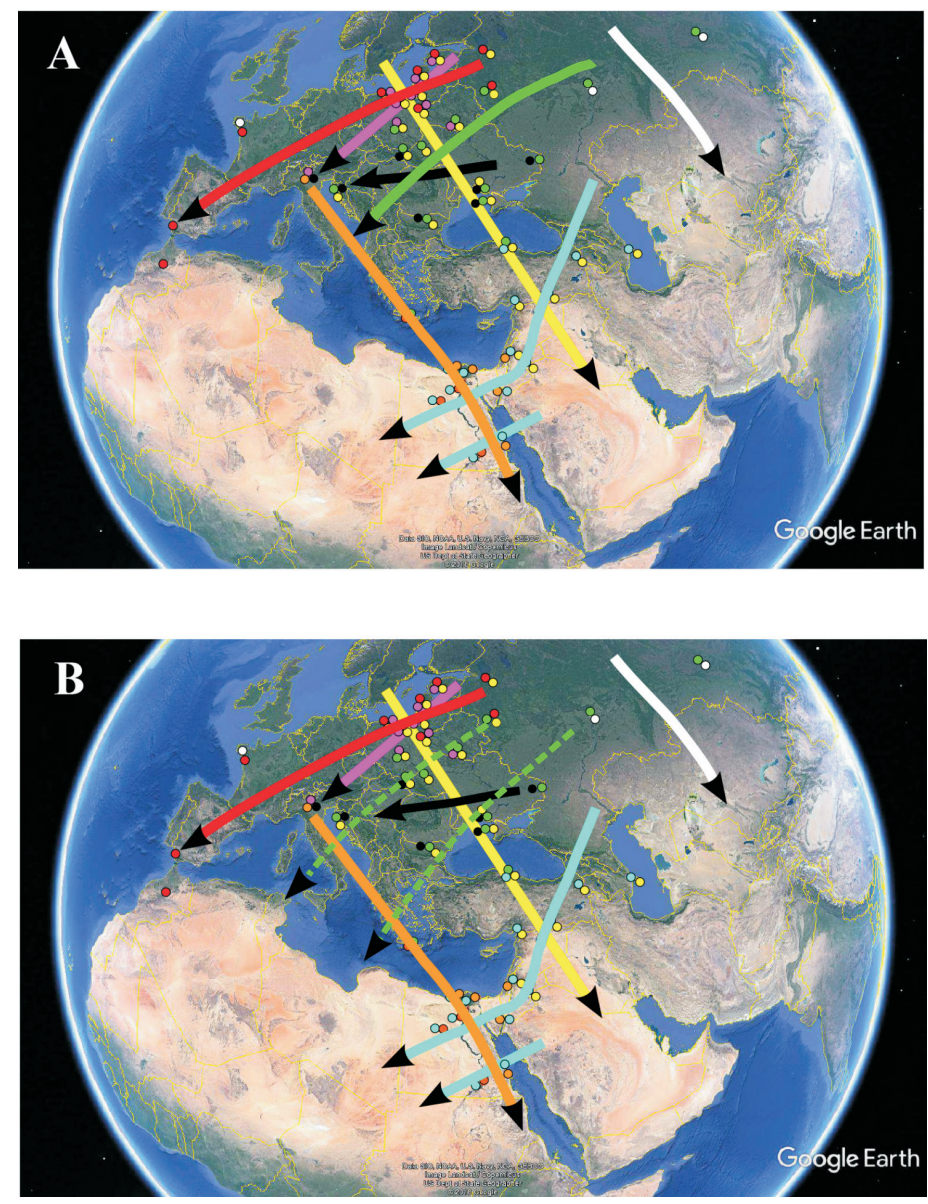

Fig. 14. General European streams of passerine migration. A and B - two alternative estimations

\section{The general migration pattern}

The general pattern is finally presented as a combination of spaces where different migratory groups were observed (Fig. 18). The Atlantic Flyway group (Red Stream - in red in Fig. 18) begins on the northwest Baltic coast, Scandinavia and the British Islands, 


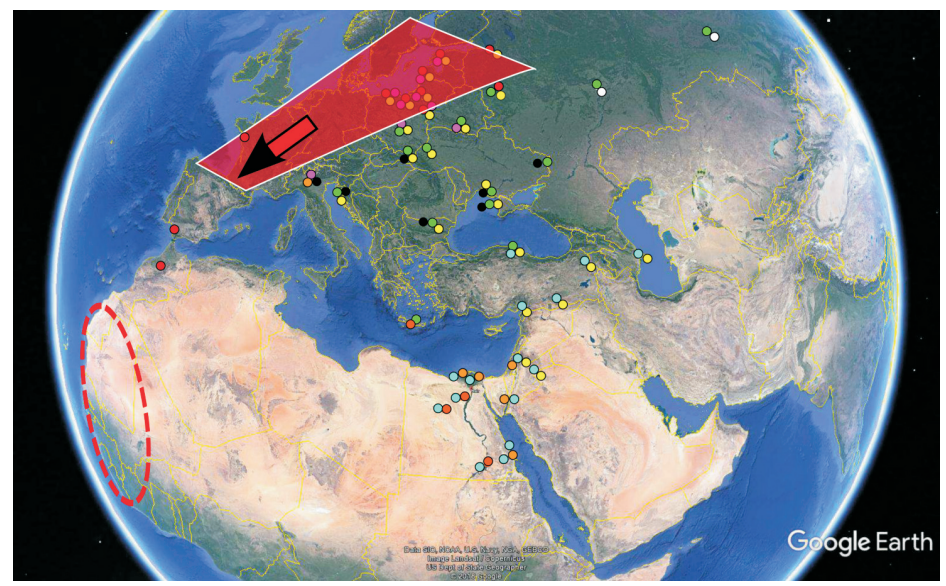

Fig. 15. An example of a "carpet" style presentation of the migration pattern of the group of birds heading to a defined area at the winter quarters. Polygon - approximate area where the defined group of migrants is visible on the site heading patterns; arrow - approximate main group heading direction; broken line circle - approximate main transit/wintering area for defined groups. Further explanations in the text p. 58.

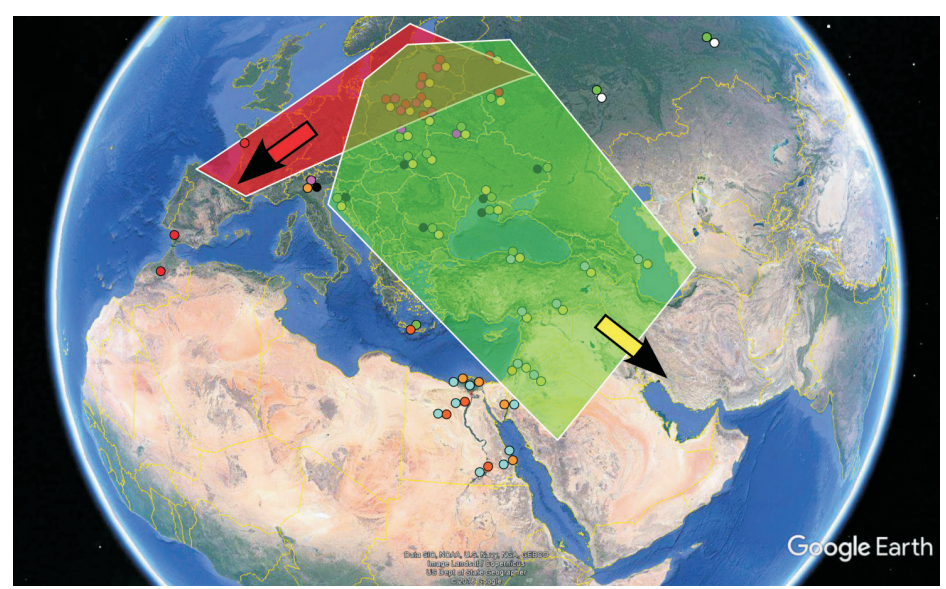

Fig. 16. Example patterns of two groups of birds migrating to different destinations. Note an area where both streams occur simultaneously. Legend as for Fig. 15.

mainly from an area outside of that covered by this study. The destination of the longdistance migrants is mainly the westernmost part of Africa. This is documented by the relatively higher number of ringing recoveries than from other parts of Africa, where the number is very small (ringing atlases: Fransson and Pettersson 2001, Wernham et al. 2002, Cepak et al. 2008, Spina et al. 2008, Bairlein et al. 2014). This migratory group contains a good share of the short-distance migrants that reach Portugal, western and southern Spain and Morocco for the winter, or stay closer, in continental Western Europe. The second, Violet Stream group, originating in the Baltic area (in violet), 

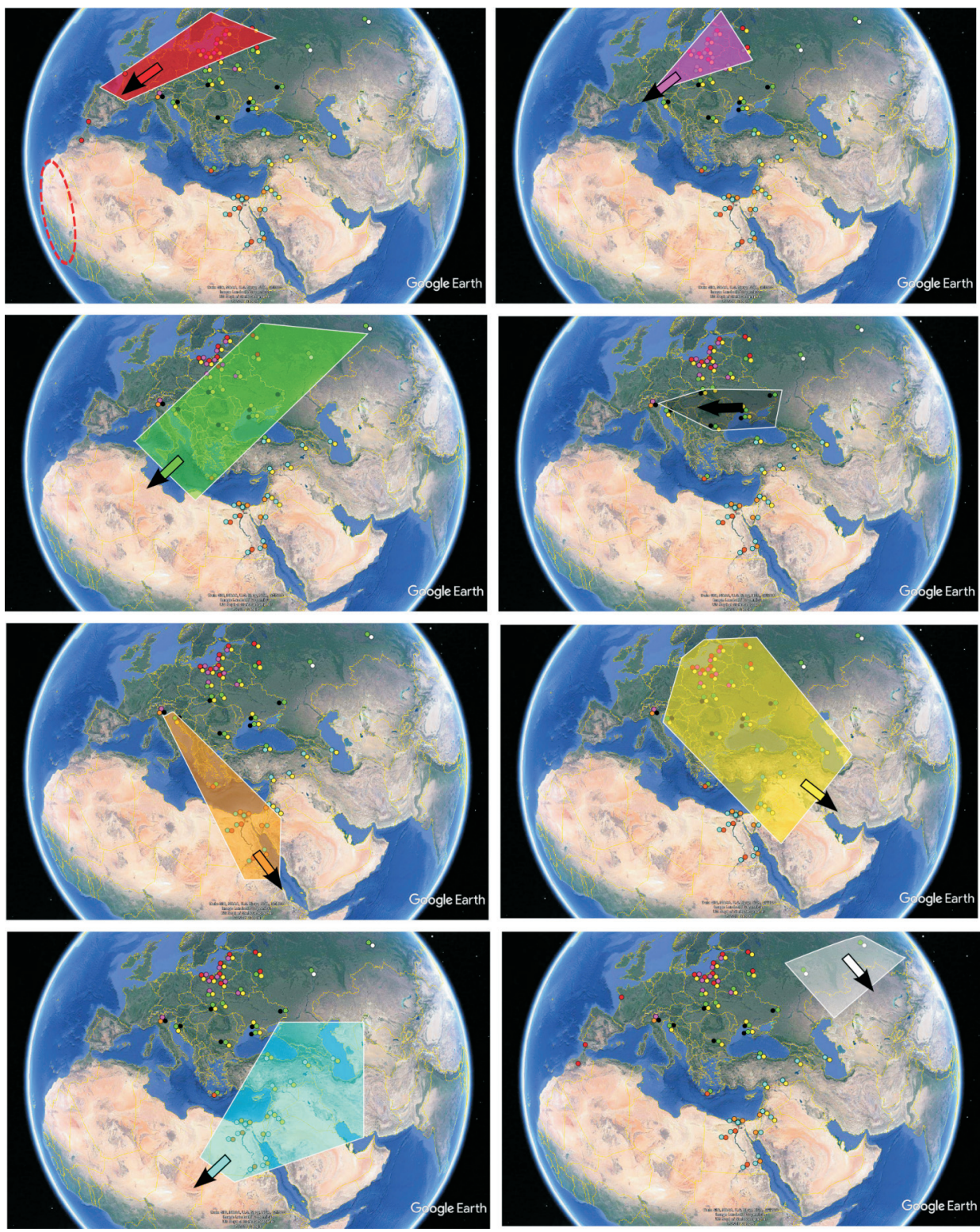

Fig. 17. Migration patterns of the bird groups identified at the study area. Legend as for Fig. 15.

heads mainly to eastern Spain, the western Mediterranean Islands and (Tunisia)/Algeria, migrating mainly north of the Alps, but whether the Black Stream group migrating south of the Alps is in fact a southern branch of the previously described Violet Stream is a problem to be solved in the future. The next stream, the Green Stream group, covers a broad area from Belarus and Ukraine through a wide territory of western Russia, even reaching the easternmost part of Siberia (Omsk site). The birds 


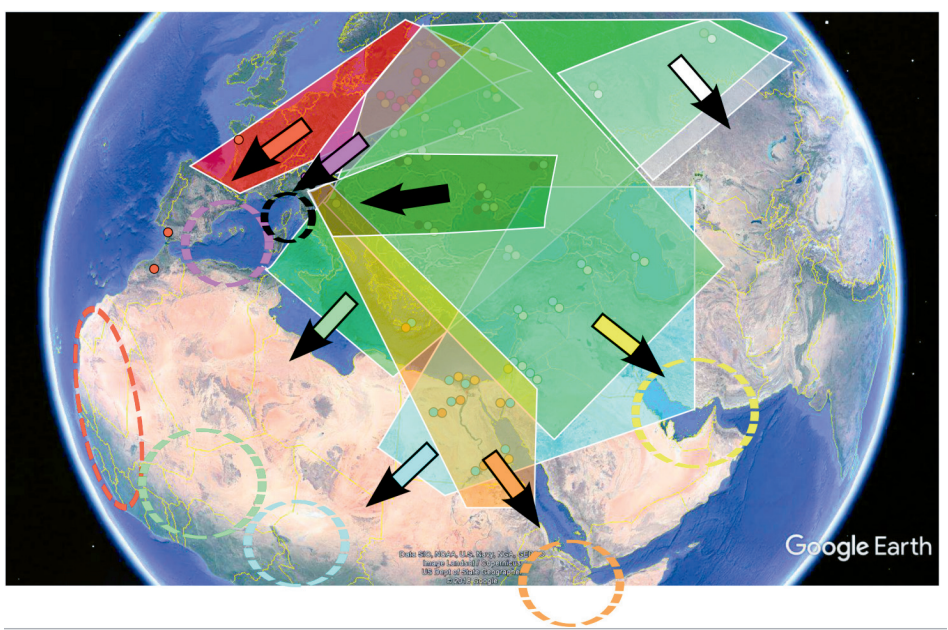

Fig. 18. General estimated patterns of passerine migration over Europe. Polygons - approximate areas where the defined groups of migrants are visible on the site heading patterns; arrows - approximate main group heading directions; broken line circles - approximate main transit/wintering areas for defined groups.

migrate SW through areas of central Italy in the west to the Sea of Azov and Turkey. As this strip is very broad, there is some question as to whether there is really one, vast carpet or if there is some internal differentiation as shown in Figure 14. The western part of that stream covers the central part of Italy, and thus territory traditionally called the Central European Flyway. However, the eastern part of the stream passes areas that were classified as the SE European Flyway (supposed migration to the SE), while birds belonging to the Green Stream actually migrate SW. On the other hand, according to the data from the sites in northern Italy, Croatia and Crete, the flow of birds is actually directed SE, heading to Egypt - the Red Sea - eastern Africa (Orange Stream). The Orange Stream is rather narrow and reaches Africa between southern Israel and western Egypt. Thus, the so-called Central European Flyway is heterogeneous, and migrants head to two different wintering territories. In the north, the source breeding area of the Orange Stream, directed SE, borders with another stream heading SE, originating in a broad territory between Scandinavia and Moscow (Zvenigorod site). These birds (Yellow Stream) head SE as the Orange Stream, but more to the east, towards the Persian Gulf (further migration is probably to East Africa, but the Arabian Peninsula is completely outside the study area). The next, White Stream, originating in the easternmost part of Europe - the Ural Mountains and further eastward, was visible only at the Makarovka and Omsk sites, because it is mainly outside the study area. Very few passerines from Eastern/Central Europe migrate to India, but the few data from Eastern Europe are insufficient to allow them to be seen at the present study sites. The next stream of migrants is clearly visible at all study sites from Turkey to the Caspian Sea: this is the Blue Stream, heading SW (perpendicular to the Yellow Stream). This stream covers the area of Jordan-PalestineIsrael and even crosses the edge of the eastern part of the Mediterranean Sea heading 
towards northern Egypt. In southern Egypt it is in part exactly parallel to the headings in the northern part of the country. In northern Egypt the headings are SW-WSW and indicate a direction towards Lake Chad. This means that these birds fly over the Sahara Desert a much longer distance than expected, rather than crossing it directly southward. In southern Egypt/the Red Sea coast, the route is a bit more southward (SW-SSW). The shortest route from the north to the south along the Nile River is not clearly visible in passerines. The Blue Stream, leading from the Black Sea-Caspian Sea through the Middle East and Egypt had not been recognized before now. It had only been mentioned for the Sedge Warbler, Acrocephalus schoenobaenus, in congress presentations by Busse (Hnatyna and Busse 2010, Busse and Abdou 2011). This claim was based on a clear SW heading of a group of adults of that species in orientation tests performed at Burullus in the Nile Delta. The same was reported for a few individuals of different species tested at the Bahariya Oasis by Stępniewski et al. (2011). These were 9 of 59 individuals tested: three Yellow Wagtails, Motacilla flava, two Willow Warblers, Phylloscopus trochilus, two Rufous Bush Robins, Cercotrichas galactotes, one Garden Warbler, Sylvia borin, and one Collared Flycatcher, Ficedula albicollis. This quite important migration stream was probably overlooked due to low passerine ringing activity at the breeding grounds and on the migration route north of the Sahara, as well as the very low ringing recovery rate at the destination areas in central Africa. According to a personal communication by R. Yosef and U. Ottosson, a few years ago there were only two or three ringing recoveries between Israel and Nigeria (at least one of the Great Reed Warbler, Acrocephalus arundinaceus). Hence it seems that this stream is quite common among passerines, but more data is needed, especially from Africa.

\section{CONCLUSION}

The migration pattern of the defined population is clearly not a 'stream-like' phenomenon, but has more of a 'carpet-like' structure. These carpets are two dimensional structures, defined not only by centres of breeding areas but also by winter-quarters (thus average headings). Hence they are described by the central stream course, but also by their width at different stages of migration. The winter-quarters of the migration group could be varied in size, due to differences in habitat selection by the member species of the group. Similarly, the breeding grounds can be species-specific due to species ecology, e.g. the dietary preferences and phenology of plants and/or other animals at breeding areas. A very important property of the streams is their independence from one another: at each site birds belonging to different populations, even of the same species, may migrate in totally different directions. Thus, for example, robins Erithacus rubecula caught one day at one site on the Baltic coast may migrate the next night in direction of France while others direct to Turkey. The local headings may be so varied that birds migrate in nearly perpendicular directions. This has already been documented for a number of species/locations following analyses of ringing recoveries (Busse 1969, Remisiewicz and Baumanis 1996, Remisiewicz 2001), as well as local evaluations of orientation cage data (Trocińska et al. 2001, For- 
mella and Busse 2002, Zehtindjiev 2003, Ściborska and Busse 2004, Adamska and Filar 2005, Adamska and Rosińska 2006, Rosińska and Adamska 2007, Stępniewska et al. 2011). However, much more can be determined even by analysing existing data from the area of this study in more detail - species by species.

\section{ACKNOWLEDGEMENTS}

The data were collected from 1995 to 2016 during field work at 45 sites in 20 countries by tens or even hundreds of professionals and volunteers. This makes it impossible to thank them individually, but they should all feel that this paper has been completed thanks to their hard work. We all participated in the network activity, as Operation Baltic, SEEN, the Atlantic Flyway Network or individual projects, by collecting the data and discussing the method of application and interpretation of the results. Thank you all, indeed.

\section{REFERENCES}

Adamska K., Filar M. 2005. Directional preferences of the Chiffchaff (Phylloscopus collybita) and the Robin (Erithacus rubecula) on autumn migration in the Beskid Niski Mountains (S Poland). Ring 27, 2: 159-176.

Adamska K., Rosińska K. 2006. Directional preferences of the Robin (Erithacus rubecula) and the Blackcap (Sylvia atricapilla) during autumn migration at Arosio (N Italy) in 2005. Ring 28, 2: 101-111.

Ashmole M. J. 1962. The migration of the European thrushes: a comparative study based on ringing recoveries. Ibis 104: 314-346.

Bairlein F., Dierschke J., Dierschke V., Salewski V., Geiter O., Hüppop K., Köppen U., Fiedler W. 2014. Atlas des Vogelzugs. Aula-Verlag Wiebelsheim.

Busse P. 1969. Results of ringing of European Corvidae. Acta Orn. 11: 263-328.

Busse P. and Abdou W. 2011. Do the Passerines cross the Sahara using the shortest way to the South, or not? $8^{\text {th }}$ Conference of the EOU, Riga, Latvia. DOI: 10.13140/2.1.4862.2401

Busse P., Kania W. 1977. A quantitative estimation of distribution of ringed birds on the basis of recovery dispersal. Not. Orn. 18: 79-93.

Busse P., Maksalon L. 1986. Migration pattern of European populations of Song Thrush. Not. Orn. 27: 3-30.

Busse P., Trocińska A. 1999. Evaluation of orientation experiment data using circular statistics doubts and pitfals in assumptions. Ring 21, 2: 107-130.

Cepak J., Klvana P., Formanek J., Horak D., Jelinek M., Schöpfer L., Skopek J., Zárybnický J. 2008. Czech and Slovak Bird Migration Atlas. Aventinum, Praha.

Coulson J. C. 1966.The movements of the Kittiwake. Bird Study 13, 2: 107-114.

Davis P. 1966. The movements of Pied wagtails as shown by ringing. Bird Study 13, 2: 147-162.

Dorst J. 1962. The Migrations of Birds. Heinemann. London-Melbourne-Toronto

Emlen S.T., Emlen J.T. 1966. A technique of recording migratory orientation of captive birds. Auk 83: 361-367.

Formella M., Busse P. 2002. Directional preferences of the Reed Warbler (acrocephalus scirpaceus) and the Sedge Warbler (A. schoenobaenus) on autumn migration at Lake Druzino (N Poland). Ring 24, 2: 15-29.

Fransson T., Pettersson J. 2001. Swedish Bird Ringing Atlas. Vol. 1. Stockholm.

Hnatyna O. and Busse P. 2010. Directional preferences, stopover and moult strategies ofthe Sedge Warbler, Acrocephalus schoenobaenus, at Burullus Lagoon, Northern Egypt. $25^{\text {th }}$ International Ornithological Congress, Brasil. DOI: 10.13140/RG.2.2.35958.24640 
Korner-Nievergelt F., Schaub M., Thorup K., Vock M. and Kania W. 2010. Estimation of bird distribution based on ring re-encounters: Precision and bias of the division coefficient and its relation to multi-state models. Bird Study 57, 1: 56-68.

Kramer G. 1949. Über Richnungstendenzen bei der nächtlichem Zugungruhe gekäftiger Vögel. In: Ornithologie als Biologische Wissenschaft. Heidelberg.

Mead C.J. 1974. The results of ringing Auks in Britain and Ireland. Bird Study 21, 1: 45-86.

Moreau R. E. 1972. The Palaearctic-African Bird Migration Systems. Academic Press. LondonNew York

Schüz E., Weigold H. 1931. Atlas des Vogelzugs nach den Beringungsergebnissen bei palärktischen Vögeln. Berlin

Remisiewicz M., Baumanis J. 1996. Autumn migration of Goldcrest (Regulus regulus) at the eastern and southern Baltic coast. Ring 18, 1-2: 3-36.

Remisiewicz M. 2001. The pattern of winter-quarters of Robins (Erithacus rubecula) migrating in autumn through the southern Baltic coast. Ring 23, 1-2: 37-53.

Rosińska K., Adamska K. 2007. Biometrics variation and directional preferences of immature Robins (Erithacus rubecula) caught in northern Italy during autumn migration in 2005. Ring 29, 1-2: 107-120.

Rudebeck G. 1956. Some aspects of bird migration in the Western palaearctic region. In Bertil Hanström. Zoological papers in honour of hissixty-fifth birthday. Lund, pp. 257-258.

Sauer E. G. 1957. Die Sternorientierungnhlih zeihender Grasmucken (Sylvia atricapilla, borin und curruca) Zeit. Tierpsychol. 14: 29-70.

Spina F., Volponi S. 2008. Atlante della Migrazione degli Ucelli in Italia. 1. non-Passeriformi. Ministero dell'Ambiente e della Tutela del Territorio e del Mare, Istituto Superiore per la Protezione e la Ricerca Ambientale (ISPRA). Tipografia SCR-Roma.

Stępniewska K., El-Hallah A., Busse P. 2011. Migration dynamics and directional preferences of passerine migrants in Azraq (E Jordan) in spring 2008. Ring 33, 1-2: 3-23.

Stępniewski K., White M.L.J., Megalli M. 2011. Autumn migration of passerines in Bahariya Oasis in Egypt - where do they come from and where do they go?. Ring 33, 1-2: 27-36.

Ściborska M., Busse P. 2004. Intraseasonal changes in directional preferences of Robins (Erithacus rubecula) caught on autumn migration at Bukowo-Kopań ringing station ( $N$ Poland). Ring 26, 1: 41-58.

Trocińska A., Leivits A., Nitecki C., Shydlovsky I. 2001. Field studies of directional preferences of the Reed Warbler (Acrocephalus scirpaceus) and the Sedge Warbler (A. schoenobaenus) on autumn migration along the eastern and southern coast of the Baltic Sea and in western part of Ukraine. Ring 23, 1-2: 109-117.

Wernham C.V., Toms M.P., Marchant J.H., Clark J.A., Siriwardena G.M., Baillie S.R. (Eds). 2002. The Migration Atlas: movements of the birds of Britain and Ireland. T. \& A.D. Poyser, London.

Zehtindjiev P., Ilieva M., Ożarowska A., Busse P. 2003. Directional behaviour of the Sedge Warbler (Acrocephalus schoenobaenus) studied in two types of orientation cages during autumn migration - a case study. Ring 25, 1-2: 53-63. 